\title{
Study on the possibility of using
} microorganisms as biological agents to control fungal pathogens Neoscytalidium dimidiatum causing disease of brown spots on the dragon fruit

\author{
Nghiên cúu khả năng sủ dụng vi sinh vật làm tác nhân sinh học kiểm soát nấm \\ Neoscytalidium dimidiatum gây bệnh đốm nâu trên cây thanh long \\ Research article
}

Luong, Huu Thanh ${ }^{1 *}$; Nguyen Kieu, Bang Tam ${ }^{2}$; Vu, Thuy Nga' ${ }^{1}$ Ha, Thi Thuy ${ }^{1}$; Tong, Hai Van ${ }^{1}$; Hua, Thi Son ${ }^{1}$; Nguyen, Ngoc Quynh ${ }^{1}$; Nguyen, Thi Hang Nga

${ }^{I}$ Department of Biological Environment, Institute of Agricultural Environment, Km No 1, Dai Mo, Phu Do, Me Tri, Ha Noi, Viet Nam; ${ }^{2}$ Department of Ecological Environment, Faculty of Environmental Sciences, VNU, Hanoi University of Science, 334 Nguyen Trai, Thanh Xuan, Hanoi, Viet Nam; ${ }^{3}$ Department of Safety and Biodiversity, Institute of Agricultural Environment, Km No 1, Dai Mo, Phu Do, Me Tri, Ha Noi, Viet Nam

\begin{abstract}
Research and application of microbial control of brown spot disease on the dragon fruit caused by fungi Neoscytalidium dimetiatum have important implications towards the safe and sustainable dragon fruit production. In this article, the research team has identified two strains of microorganisms capable of inhibiting fungi Neoscytalidium dimitiatum denoted A3, B7. Classification results determined that A3 belongs to Actinomyces group 3 with similarities of $100 \%(1500 / 1500 \mathrm{bp})$ with $16 \mathrm{~S}$ rDNA segment of Streptomyces fradiae; B7 with similarities of $100 \%$ (1414/1414 bp) with $16 \mathrm{~S}$ rDNA segment of bacteria Bacillus polyfermenticus and ensure biosafety when released into the environment.
\end{abstract}

\begin{abstract}
Nghiên cứu ứng dụng vi sinh vật kiểm soát bệnh đốm nâu trên cây thanh long do nấm Neoscytalidium dimetiatum gây ra có ý nghĩa quan trọng huớng tới ngành sản xuất thanh long an toàn và bền vĩng. Trong bài viết này nhóm nghiên cưu đã xác định được hai chủng vi sinh vật có khả năng ức chế nấm Neoscytalidium dimitiatum cao kí hiệu là A3, B7. Kết quả phân loại xác định chủng A3 thuộc nhóm xạ khuẩn 3 tuơng đồng 100\% (1500/1500 bp) với đoạn $16 \mathrm{~S}$ rDNA của Streptomyces fradiae; chủng B7 tưong đồng $100 \%$ (1414/1414 bp) với đoạn 16 của vi khuấn Bacillus polyfermenticus và đảm bảo an toàn sinh hoc khi phóng thích ra môi truòng.
\end{abstract}

Keywords: brown spot disease, dragon fruit, Neoscytalidium dimetiatum, Streptomyces fradiae, Bacillus polyfermenticus

\section{Introduction}

Dragon fruit is a fruit of the high export value, were grown in Binh Thuan, Long An, Tien Giang. However in recent years, the pest is causing a reduction in productivity, product quality, especially brown spots on fruit caused by fungi Neoscytalidium dimidiatum (belong to the Botryosphaeriaceae family; the Botryosphaeriales ordor; the Ascomycetes class). Current conditions are very complicated movements, spread across the board, thrive in the rainy season. Use of plant protection chemicals Azoxystrobin origin, Sifenoconazole may control brown spot disease fairly efficient, but drug residues in plant products is the biggest barrier to export dragon fruits to the fastidious markets as EU, US, Japan etc. [1]. Research using microorganisms as biological agents to control brown spots on dragon fruits is a positive direction to meet requirements for product safety to export, for domestic consumption as well as 
contributing to reducing the use of chemicals in agriculture [2].

\section{Material and methods}

\subsection{Research materials}

- Fungi Neoscytalidium dimidiatum were provided by Southern Institute of fruit trees.

- Soil samples were taken from dragon fruit cultivation in Binh Thuan, Tien Giang, Long An.

\subsection{Research methods}

- Identification of microbial density: grow microorganisms on the agar dish medium, count the number of microorganisms per $\mathrm{ml}$ or per gram samples through development of colonies in the dish environment [3].

- Identification of the biological activity (ability to inhibit fungi) by the method of measurement of diffusion diameter on agar medium [3].

- Method of determining the names and biosafety of microorganisms [4,5,6]: Using molecular biology techniques to interpret sequences of ribosomal RNA gene segments $16 \mathrm{~s}$ of studied strains, compared with the sequences available in the international bank gene EMBL by FASTA 3 to identify to species 33 strains of microorganisms. Primers were designed based on the sequence of encoded gene fragment of ribosomal RNA $16 \mathrm{~s}$ of the strain of E. coli (JO1695), corresponding to nucleotide positions 15-33 (for forward primer) and 1548-1532 (for reverse primer). Nucleotide sequences of the strains studied are detailed in ABI-377 automatic machine Perkin-Elmer's company (USA), which is then processed by the program SeqEdl.03 and the program AssemblyLING 1,9 in program relation MacVector 6.5.3 (Oxford Molecular Inc.). Access gene by program Entrez gene / nucleotide / identify gene sequence of ribosomal RNA $16 \mathrm{~s}$ of bacteria. Comparating and processing of all chain data by program GENDOC2.5. Nucleotid components were included using the code of low levels of microorganisms (bacteria) in the Gene Bank (genetic code table No. 11) through the program GENDOC.

- Names of microorganisms are identified with the highest probability of similarity. To compare "the lists of safe microorganisms of European Community" as well as "the list of microbial species are restricted to use" to determine the safety of selected microorganisms.

The experiments were conducted at the Institute of Agricultural Environment - Ministry of Agriculture and Rural Development, Ha Noi University of Science - Vietnam National University.

\section{Results and discussion}

\subsection{Selection of microorganisms with ability to inhibit fungi Neoscytalidium dimidiatum}

From soil samples that were taken in Binh Thuan, Long An, Tien Giang research group has conducted the isolation and selection of some microbial strains, which have inhibitory activity on Neoscytalidium dimidiatum (Table 1).

Table 1. Isolated strains with inhibitory ability on Neoscytalidium dimimtiatum

\begin{tabular}{cccccc}
\multirow{2}{*}{ No } & Strain symbol & Origin & Microbial group & \multicolumn{2}{c}{ Diameter of fungal inhibitory circle (D-d)mm } \\
\cline { 5 - 6 } & & & Test & Control \\
\hline 1 & B1 & Binh Thuan & Actinomyces & $15.5 \pm 3$ & 0 \\
2 & B6 & Binh Thuan & Bacteria & $12.5 \pm 3$ & 0 \\
3 & B7 & Binh Thuan & Bacteria & $23.0 \pm 3$ & 0 \\
4 & B4 & Binh Thuan & Actinomyces & $15.0 \pm 3$ & 0 \\
5 & A1 & Tien Giang & Bacteria & $13.0 \pm 3$ & 0 \\
6 & A2 & Tien Giang & Bacteria & $16.0 \pm 3$ & 0 \\
7 & A3 & Tien Giang & Actinomyces & $21.0 \pm 3$ & 0 \\
8 & C1 & Long An & Bacteria & $16.0 \pm 3$ & 0 \\
9 & C3 & Long An & Bacteria & $17.0 \pm 3$ & 0 \\
10 & C4 & Long An & Bacteria & $18.0 \pm 3$ & 0
\end{tabular}

From soil samples in Binh Thuan, Tien Giang and Long An, 10 strains of microorganisms with inhibitory ability on Neoscytalidium dimitiatum have been isolated, of which 7 strains belong to bacteria group and 3 strains belong to actinomyces group.

Results of bioactivity evaluation by method of diffusion on agar showed that in the control formula (using sterilized distilled water) did not appear inhibitory circles. In Table 1, A1 strain has low capable of inhibiting fungus $\mathrm{Ne}$ oscytalidium dimitiatum (inhibition ring diameter =
$13.0 \mathrm{~mm}), \mathrm{A} 3$ and $\mathrm{B} 7$ have diameters with the highest inhibition $(21.0 \pm 3$ and $23.0 \pm 3 \mathrm{~mm})$ and was selected for the next study.

\subsection{Biochemical characteristics of microor- ganism strains}

- Physiological, morphological characteristics of strain B7: B7 colonies were cultured on medium $\mathrm{KB}$ had round shapes, serrated edge, white milk color (Fig.1). Shaking culture on liquid medium after 48 hours, cell density reached the highest of $7.10^{9} \mathrm{CFU} / \mathrm{ml}$ (Table 2). 
- Physiological, morphological characteristics of strain A3: A3 colonies were grown on medium Gauze had round shapes, diameters of $2.2-2.5 \mathrm{~mm}$, pinkish color, colony legs sticking deep in the medium (Fig.1). Shaking culture on liquid medium, after 72 hours, small particles about $1 \mathrm{~mm}$ were formed to make white scum forming rounds on the culture medium and on the container wall, clinging to the walls of the flask, cell density reached $2.10^{9} \mathrm{CFU} / \mathrm{ml}$ (Table 2).

Table 2. Suitable culture conditions for growth and development of A3 and B7

Culture conditions
Temperature(oC)
DH
Demand for $\mathrm{O}_{2}$ (gas supply, $\mathrm{dm}^{3} \mathrm{O}_{2} / \mathrm{dm}^{3}$ environment/
h)

Incubation time $(\mathrm{h})$

Carbohydrate source

Nitrogen source

Cell density (CFU/ml)

The study results showed that B7 anh A3 strains can grow well in normal conditions and in culture media with sources of $\mathrm{C}, \mathrm{N}$ nutrients commonly used in laboratories.

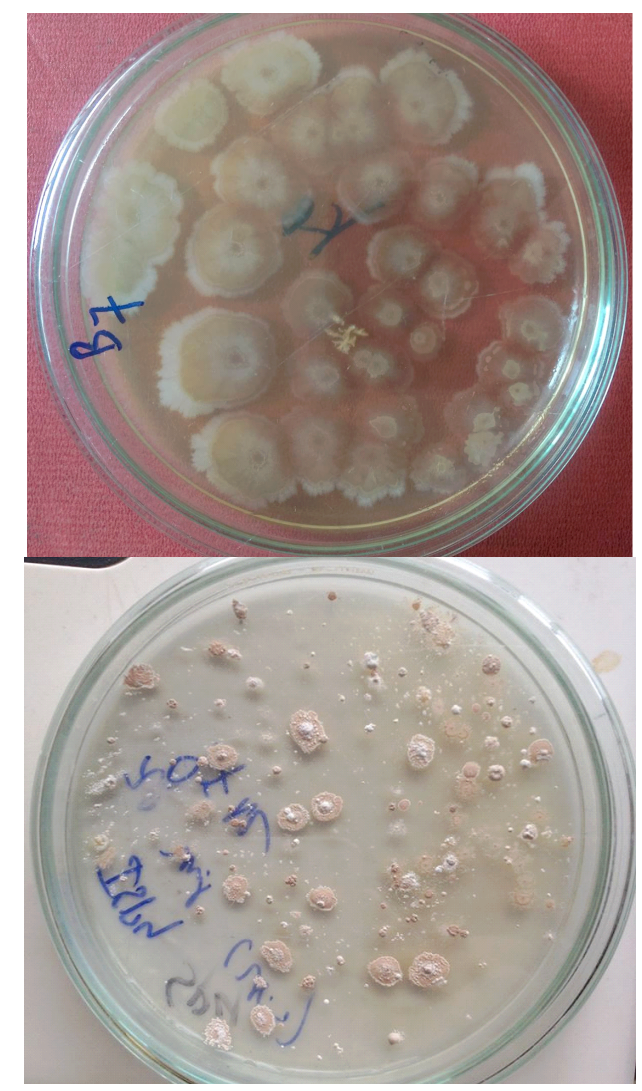

Figure 1. Colony image of strains B7, A3

\subsection{Identification of microbial strains used in the study}

16S rRNA gene sequence of B7 has similarity of $100 \%$ (1414/1414 bp) with the 16s segment of bacteria Bacillus polyfermenticus; similarity of $99.9 \%$ (1413/1414 bp) with 16s segment of Bacillus axarquiensis, Brevibacterium halotolerans. Based on the results of genetic sequencing and biochemical characteristics, characteristics of strains B7
Identified results

\begin{tabular}{cc}
\hline $\mathbf{B 7}$ & $\mathbf{A 3}$ \\
\hline $35 \pm 2$ & $35 \pm 2$ \\
$6.0-7.5$ & $6.0-7.5$ \\
0.75 & 0.75 \\
48 & 72 \\
Glycerol, starch, molasses & malt extract, dextrose, \\
Pepton, yeast extract & Pepton, yeast extract \\
$7.10^{9}$ & $2.10^{9}$
\end{tabular}

coincided with bacteria called Bacillus polyfermenticus (Figure 2).

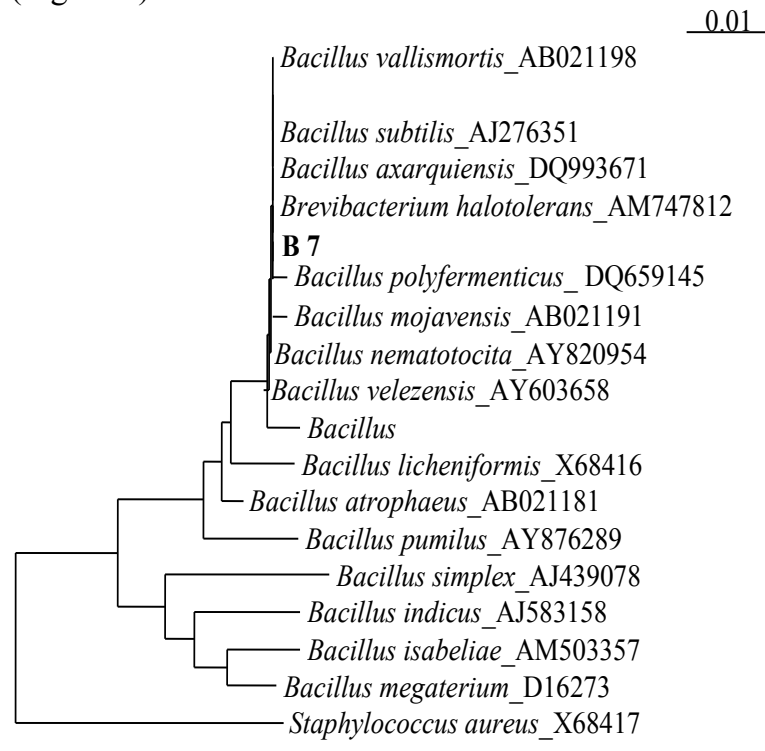

Figure 2. Classification tree of strain $B 7$

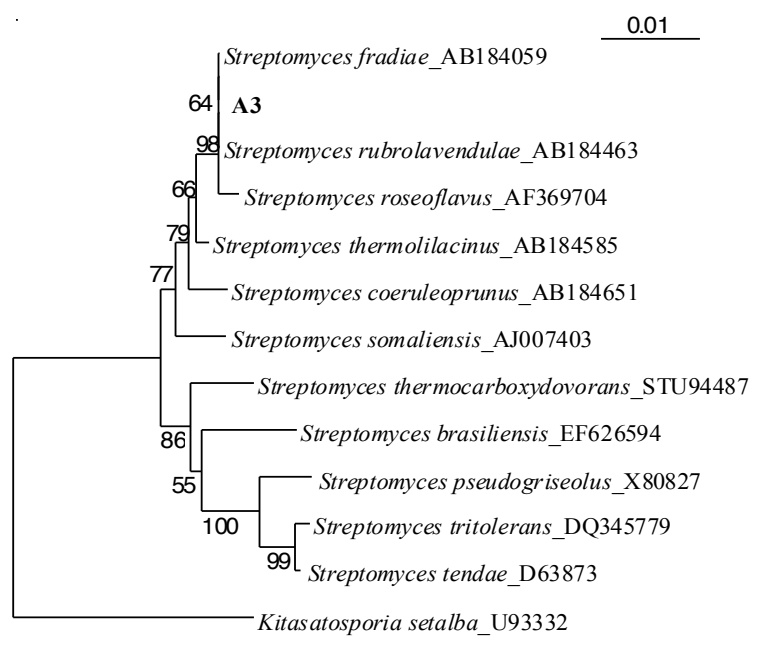

Figure 3. Classification tree of strain A3

16s rRNA sequences of strain A3 had similarity of 100\% $(1500 / 1500 \mathrm{bp})$ with $16 \mathrm{~S}$ rDNA segment of Streptomyces 
fradiae and Streptomyces rubrolavendulae; 99.8\% (1497/1500 bp) with Streptomyces roseoflavus. Based on the results of genetic sequencing and biochemical characteristics of the study actinomycetes, characteristics of strain A3 coincided with actinomyces called Streptomyces fradiae (Figure 3).

The results compared with the biosafety list (According to Directive No 90/679 / EWG of the European Communities on Biosafety) show that bacteria (Bacillus polyfermenticus) and actinomyces (Streptomyces fradiae) were classified as microorganisms with biosafety level 2, can be widely applied to make antifungal preparations for $\mathrm{Ne}$ oscytalidium dimimtiatum.

\section{Conclusions and recommendations}

\subsection{Conclusions}

1. From the samples collected in the dragon land area in Binh Thuan, Tien Giang, Long An team, 10 strains of microorganisms with inhibitory ability on growth of pathogenic fungi Neoscytalidiumdimitiatum have been isolated.

2. Strains A3 has inhibitory ring diameter of $21.0 \pm 3 \mathrm{~mm}$; strain B7 inhibits Neoscytalidiumdimitiatum with inhibitor ring diameter of $23.0 \pm 3 \mathrm{~mm}$. Classification results determined that strain A3 belongs to actinomyces group with similarities of $100 \%(1500 / 1500 \mathrm{bp})$ with $16 \mathrm{~S}$ rDNA segment of Streptomyces fradiae; B7 belongs to bacteria group with similarities of $100 \%$ (1414/1414 bp) with 16 s segment of Bacillus polyfermenticus.

3. According to biosafety levels of the fungi under the Common Criteria of the European Community, the two microorganism strains are classified as microorganisms with biological safety level 2, are allowed to use in the production and release into the environment and can be used as research material probiotics fungicides on $\mathrm{Ne}$ oscytalidium dimitiatum.

\subsection{Request}

Propose further study to complete production technology to make microbial preparations preventing fungal microorganisms Neoscytalidium dimitiatum, quickly bring products and applications into production.

\section{References}

[1] Plant Protection Department, 2014. The situation on the dragon pests and resolve phytosanitary barriers to export dragon fruit from Vietnam. Report of the Conference on "Dragon fruit sustainable Production and market development" on 05.15.2014 in Binh Thuan.

[2] Nguyen Hong Son, Nguyen Thanh Hieu, Nguyen Thi Bich Ngoc, Tran Minh Tien, Mai Thi Thuy Kieu, Nguyen Thi Thu Vinh, 2015. Findings some urgent measures to limit the spread and effects of dragon brown spot caused by fungi Neoscytalidium dimidiatum, Journal of Agriculture and Rural Development, 9/2015, 27-32

[3] [3] The Ministry of Agriculture and Rural Development 2006. "Microbiology - Evaluation method for antifungal activity that causes shallow root zone of the plant." 10TCN 867: 2006.

[4] Nguyen Thanh Hieu, Nguyen Ngoc Anh Thu and Nguyen Van Hoa, 2014. The study identified factors, morphological and biological properties of pathogenic fungi Neoscytalidium dimidiatum causing brown spot on the dragon fruit plants (Hylocereus undatus). National Workshop "Vietnam Plant Diseases" 13th, held at the Ho Chi Minh City University of Agriculture and Forestry. Ho Chi Minh City, 6-7 / 5/2014, 114-120.

[5] J. Sambrook J. and D. Russell, 2001. Cold Spring Harbor Laboratory Press, Cold Spring Harbor, New York.

[6] Lane D. J, 1991. 16S/23S rRNA sequencing. In: Nucleic Acid Techniques in Bacterial Systematics, pp. 115-175. Edited by E. Stackebrandt \& M. Goodfellow. Chichester: Wiley. 